\title{
Serological response to rabies virus induced by commercial vaccines in cattle
}

\author{
Mathias Martins ${ }^{1}$ João Motta de Quadros ${ }^{2}$ \\ Eduardo Furtado Flores $^{2^{*}}$ Rudi Weiblen ${ }^{2}$
}

'Programa de Pós-graduação em Medicina Veterinária, Universidade Federal de Santa Maria (UFSM), Santa Maria, RS, Brasil. ${ }^{2}$ Setor de Virologia, Departamento de Medicina Veterinária Preventiva, Centro de Ciências Rurais (CCR), Universidade Federal de Santa Maria (UFSM), 97105-900, Santa Maria, RS, Brasil. E-mail: eduardofurtadoflores@gmail.com. "Corresponding author.

\begin{abstract}
The antibody response to rabies virus (RABV) induced by commercial vaccines in heifers was investigated. For this, 84 heifers were vaccinated twice (30 days interval) with each of four vaccines ( $G 1=14$ animals; $G 2=24 ; G 3=22$ and $G 4=24$ ) and received a booster vaccination 360 days later. Serum samples collected at different intervals after vaccination and 30 days after booster were submitted to a virus neutralizing (VN) assay for RABV antibodies. Thirty days after the second vaccine dose, 92\% of the immunized animals presented VN titers $\geq 0.5 \mathrm{UI} / \mathrm{mL}$ (geometric medium titers [GMT] 1.7 to $3.8 \mathrm{UI} / \mathrm{mL}$ ). At the day of the booster (360 days post-vaccination); however, the percentage of animals harboring antibody titers $\geq 0.5 U \mathrm{UI} / \mathrm{mL}$ had dropped to $31 \%$ (0-80\% of the animals, depending on the vaccine), resulting in lower GMT (0.1 to 0.6UI/mL). Booster vaccination at day 360 resulted in a detectable anamnestic response in all groups, resulting in $83 \%$ of animals (65 to $100 \%$ ) harboring $V N$ titers $\geq 0.5 U I / m L$ thirty days later (GMT 0.6 to $4.3 U I / m L$ ). These results indicated that these vaccines were able to induce an adequate anti-RABV response in all animals after prime vaccination (and after booster as well). However, the titers decreased, reaching titers $<0.5 \mathrm{UI} / \mathrm{mL}$ in approximately $70 \%$ of animals within the interval before the recommended booster. Thus, booster vaccination for rabies in cattle using the current vaccines should be performed before the recommended one-year interval, as to maintain neutralizing antibodies levels in most vaccinated animals.
\end{abstract}

Key words: rabies, cattle, vaccines, neutralizing antibodies.

Resposta sorológica ao vírus da raiva induzida por vacinas comerciais em bovinos

RESUMO: A resposta sorológica contra o vírus da raiva (RABV) induzida por vacinas comerciais foi investigada em bovinos. Para isso, 84 novilhas foram vacinadas duas vezes (30 dias de intervalo) com cada vacina $(G 1=14$ animais; $G 2=24 ; G 3=22$ e G4=24) e receberam uma vacinação de reforço 360 dias depois. Amostras de soro coletadas em diferentes momentos após a vacinação e após o reforço vacinal foram submetidas ao teste de vírus neutralização (VN) para deteç̧ão de anticorpos contra o RABV. Trinta dias após a segunda dose vacinal, $92 \%$ dos animais apresentaram títulos neutralizantes $\geq 0,5 U I / m L$ (GMT 1,7 a 3,8UI/mL). Porém, no dia do reforço (360 dias pós-vacinação), a porcentagem de animais que ainda apresentava titulos $\geq 0,5 \mathrm{UI} / \mathrm{mL}$ havia se reduzido a $31 \%$ dos animais ( 0 a $80 \%$, dependendo da vacina), resultando em baixos TMGs $(0,1$ a 0,6UI/mL). A vacinação de reforço no dia 360 resultou em resposta anamnéstica em todos os grupos, resultando em $83 \%$ (65 a 100\%) de animais com títulos $V N \geq 0,5 \mathrm{UI} / \mathrm{mL}$ trinta dias após (GMT 0,6 a 4,3UI $\mathrm{mL}^{-1}$ ). Esses resultados indicam que as vacinas avaliadas induzem uma resposta adequada de anticorpos anti-RABV após a vacinação (e também após o reforço). No entanto, os títulos reduzem-se, atingindo niveis $<0,5 \mathrm{UI} / \mathrm{mL}$ em $70 \%$ dos animais durante o intervalo antes do reforço. Assim, vacinação de reforço contra a raiva em bovinos, utilizando-se as vacinas atuais, deve ser realizada em intervalo inferior a um ano, de forma a manter os niveis de anticorpos neutralizantes na maioria dos animais.

Palavras-chave: raiva, bovinos, vacinas, anticorpos neutralizantes.

\section{INTRODUCTION}

Rabies is an acute and generally fatal neurological disease of mammals, including humans. Annually, an estimated number of 60.000 people die of rabies worldwide, manly in African and Asian countries
(OIE, 2016). The disease is caused by rabies virus (RABV), an enveloped RNA virus belonging to the family Rhabdoviridae, genus Lyssavirus (ICTV, 2015). $\mathrm{RABV}$ is maintained in nature in cycles involving wild and domestic animals, noticeably carnivores and bats (CONDORI-CONDORI et al., 2013). In South America, 
the bat Desmodus rotundus is the main reservoir of RABV in nature, with frequent transmission to livestock, mainly cattle, horses and sheep (SCHNEIDER et al., 2009).

The economic losses associated with bovine rabies in Latin America may reach 15 million dollars, due to approximately 100 at 500 thousand deaths every year (HEINEMANN et al., 2002). Bovine rabies is endemic in most Brazilian regions represents an important sanitary and economic problem (HEINEMANN et al., 2002). Although, rabies is considered endemic in Brazil, the index varies between different regions of the country. Estimates of deaths reach up to 30.000 to 40.000 cattle annually (RODRIGUES DA SILVA et al., 2000; HEINEMANN et al., 2002).

Rabies vaccination is widely used in Brazilian regions where RABV infection is endemic, frequently associated with control of bat populations Desmodus rotundus (JOHNSON et al., 2014). Unfortunately, vaccination seems not to confer complete protection since bovine rabies has been reported even in vaccinated animals (LIMA et al., 2005). Indeed, some studies revealed a fast drop in neutralizing antibodies after vaccination, what could partially explain some vaccine failures (RIBEIRO NETTO et al., 1973; ALBAS et al., 1998; QUEIROZ DA SILVA et al., 2003). In addition, experimental data has demonstrated that booster vaccinations at somewhat short intervals are required for maintain adequate $\mathrm{VN}$ antibody titers (ITO et al., 1991; CÔRTES et al., 1993; RODRIGUES DA SILVA et al., 2000). Protection to RABV infection induced by vaccination is based mainly on neutralizing antibodies directed to the envelope glycoprotein G (WIKTOR et al., 1973; WUNDERLI et al., 1991). According to OIE, immunized animals must have levels of neutralizing antibodies of $\geq 0.5 \mathrm{UI} / \mathrm{mL}$.

Several inactivated, adjuvanted vaccines are available commercially and are widely used in Brazilian regions endemic for rabies. Licensed vaccines are subjected to an official quality control (MAPA, 2009). In spite of the manufacturer's instructions (two 30-days apart initial doses followed by annual boosters), some producers perform only a single prime vaccination followed by occasional boosters, usually when cases of rabies are reported nearby (LIMA et al., 2005). The absence or incomplete vaccination protocols performed in most herds certainly contributes for the reported cases of rabies in vaccinated animals (FILHO et al., 2010; JOHNSON et al., 2014).

In Rio Grande do Sul (RS), the southernmost Brazil State, bovine rabies was historically endemic in well defined, restricted regions (FLORES - verbal report). Hence, vaccination was usually restricted to the affected and nearby herds. Beginning in 2011, an unprecedented rabies outbreak is occurring in the state, with estimates reaching up to 40.000 deaths by 2013 (SEAPA, 2013). In addition to the dramatic increase in the number of cases, the distribution of the disease also changed, with cases/outbreaks occurring in otherwise free areas. As a consequence of the increase in the number of cases and expansion of the affected areas, rabies vaccination has been gradually implemented in many RS regions (FLORES - verbal report). Thus, the objective of this study was to evaluate the serological response of cattle to four commercial rabies vaccines, used according to the manufacturer's recommendations.

\section{MATERIALS AND METHODS}

Eighty-four heifers (12 to 24 months-old) belonging to herds with no historic of vaccination against rabies in the central region of RS were used. Heifers were randomly allocated in four groups, each group receiving one commercial rabies vaccine, as follows: $\mathrm{G} 1=14$ animals; $\mathrm{G} 2=24 ; \mathrm{G} 3=22$ and $\mathrm{G} 4=24$. The four vaccines have been purchased in veterinary stores, kept refrigerated and used before the expiration date. All vaccines contain the RABV strain Pasteur virus (PV) inactivated and aluminum hydroxide as adjuvant. Animals were vaccinated according to the manufacturer's instructions, receiving two doses subcutaneously $(2 \mathrm{~mL})$ with a 30 day-interval, followed by a booster approximately 360 days later. Serum samples were collected at days 0 (first vaccine dose), 30 (second dose), 60, 360 (day of the booster) and 390 (30 days after booster). Serum samples were submitted to a modified RIFFT (rapid inhibition fluorescent focus test) for neutralizing antibodies to RABV, according to SMITH et al. (1973), with minor modifications. Briefly, 10-fold dilutions of serum were incubated with approximately $100-200 \mathrm{TCID}_{50}(50 \%$ tissue culture infective dose) of CVS (Challenge Virus Standard - CVS132-11A), kindly provided by Instituto Pasteur, São Paulo, Brazil) for 90min, followed by addition of a suspension of Baby Hamster Kidney cells (BHK-21 - C-13 $\mathrm{ATCC}^{\circledR} \mathrm{CCL}-10^{\mathrm{TM}}$ ) and incubation at $37^{\circ} \mathrm{C}-5 \%$ of $\mathrm{CO}_{2}$ for $48 \mathrm{~h}$. At the end of this period, the indicator cells were submitted to a fluorescent antibody (FA) assay, using an anti-RABV FITC-conjugate (Instituto Pasteur, São Paulo, Brazil). Mock-infected BHK-21 cells and cells infected with CVS were used as controls. Slides were observed in an UV epifluorescence microscope (Axiolab ZEISS ${ }^{\circledR}$ ). The virus neutralizing (VN) titer was considered the highest dilution of serum able to prevent virus replication, as indicated by the absence of viral antigens in indicator cells. A reference serum (containing $0.5 \mathrm{UI} / \mathrm{mL}$, provided by Instituto Pasteur, Sao Paulo, Brazil) was used as control in all tests. The neutralizing 
titer of this serum was used to convert the $\mathrm{VN}$ titers of the samples to UI $\mathrm{mL}^{-1}$. Neutralizing titers were converted to GMT according to PERKINS (1958). The GMT for each vaccine group at different intervals were submitted to statistical analysis, using the ANOVA and test of the Tukey in software Assistat version 7.7 beta.

\section{RESULTS AND DISCUSSION}

The results of RIFFT assays for RABV neutralizing antibodies in the sera of heifers immunized with commercial vaccines are presented in table 1 and figure 1. Table 1 presents the number and percentage of seropositive cattle (titers $\geq 0.5 \mathrm{UI} / \mathrm{mL}$ ) and the GMT of the vaccinated animals after vaccination and booster; figure 1 shows the evolution of VN titers (expressed as GMT) at these time points.

None of the vaccinated animals had VN antibodies to RABV at the day of first vaccination, as verified by the RIFFT (not shown). Thirty days after the first vaccine dose, $57 \%$ of the animals presented $\mathrm{VN}$ titers $\geq 0.5 \mathrm{UI} / \mathrm{mL}$ (Table 1 ). The percentage of seropositive cattle varied among the groups, from $25 \%$ (G2) to $86 \%$ (G1). The GMT at this day ranged from 0.3 (G2) to $1.4 \mathrm{UI} / \mathrm{mL}(\mathrm{G} 1)$. In naïve animals, a single dose of inactivated rabies vaccine has been considered insufficient for adequate immunization (ALBAS et al., 1998; FILHO et al., 2010). ALBAS et al. (2005) compared different vaccination protocols with a commercial vaccine containing inactivated RABV (strain PV) and aluminum hydroxide as adjuvant. When evaluating the neutralizing antibody titers 30 days after the first vaccination, only $30 \%$ of the animals had developed neutralizing antibodies in titers $\geq 0.5 \mathrm{UI} / \mathrm{mL}$. Our results corroborated these findings, demonstrating that a single dose of the current inactivated vaccines is insufficient to induce suitable antibody levels. However, it should be emphasized that seroconversion at day 30pv (post-vaccination) should not be considered a definitive indicator of vaccine immunogenicity since the vaccine protocols recommend two initial doses 30 days apart. Unfortunately, many Brazilian farmers do not perform the complete vaccination protocol, applying only a single dose. According to our study and previous results, this simplified protocol results in low antibody titers and/or in a low percentage of seropositive cattle, leaving unprotected a considerable part of the herd (ALBAS et al., 2005).

At day 60 (30 days after the second vaccine dose), the heifers had seroconverted to RABV in titers $\geq 0.5 \mathrm{UI} / \mathrm{mL}$ in percentages of $100 \%$ (G1), $95 \%$ (G2 and G3) and 76\% (G4), respectively. The GMT ranged from $1.0(\mathrm{G} 4)$ to $3.8 \mathrm{UI} / \mathrm{mL}(\mathrm{G} 1)$. Again, G1 heifers developed the highest VN titers comparing to the other groups $(\mathrm{P}<0.05)$. Thus, considering the recommended protocol of two initial doses, three out of four vaccines were able to induce $\mathrm{VN}$ titers above the cut-off value recommended by OIE $(\geq 0.5 \mathrm{UI} / \mathrm{mL})$ against $\mathrm{RABV}$ in at least $95 \%$ of heifers. Surprisingly, only $76 \%$ of the animals of one vaccine group (G4) developed antibody titers higher than $0.5 \mathrm{UI} / \mathrm{mL}$ after the second dose. The reasons for this low performance are unclear and somewhat surprising since these vaccines are expected to fulfill the official requirements that include innocuity, sterility and potency before are made available for commercial use (MAPA, 2009).

In general, the $\mathrm{VN}$ titers at day 60 were well above the reference value, in at least three vaccine groups (in some cases they reached up to $8 \mathrm{UI} / \mathrm{mL}$ ). The magnitude of VN titers, as indicated by GMT, was highly variable among the groups, indicating important differences in the immunogenicity among the vaccines.

Table 1 - Serological response of heifers to rabies virus following vaccination and booster with each of four commercial rabies vaccines.

\begin{tabular}{|c|c|c|c|c|c|c|c|c|c|c|}
\hline \multicolumn{2}{|c|}{-------Day------- } & \multicolumn{2}{|c|}{------------30pv ${ }^{1}-----------$} & \multicolumn{3}{|c|}{-----------------60pv----------------- } & \multicolumn{2}{|c|}{------------360pv----------- } & \multicolumn{2}{|c|}{---------390pv--------- } \\
\hline Group & $n$ & $\begin{array}{c}\% \text { seropositive } \\
\text { cattle }^{2}\end{array}$ & $\mathrm{GMT}^{3}$ & $\begin{array}{c}\% \text { seropositive } \\
\text { cattle }\end{array}$ & GMT & $n$ & $\begin{array}{c}\% \text { seropositive } \\
\text { cattle }\end{array}$ & GMT & $\begin{array}{c}\% \text { seropositive } \\
\text { cattle }\end{array}$ & GMT \\
\hline G 1 & 14 & $86(12 / 14)$ & 1.4 & $100(14 / 14)$ & 3.8 & 10 & $80(8 / 10)$ & 0.6 & $100(10 / 10)$ & 4.3 \\
\hline G 2 & 24 & $25(6 / 24)$ & 0.3 & $95(23 / 24)$ & 1.9 & 17 & $23(4 / 17)$ & 0.2 & $65(11 / 17)$ & 0.8 \\
\hline G 3 & 22 & $73(16 / 22)$ & 0.5 & $95(21 / 22)$ & 1.7 & 15 & $27(4 / 15)$ & 0.1 & $87(13 / 15)$ & 0.6 \\
\hline G 4 & 24 & $58(14 / 24)$ & 0.5 & $76(19 / 24)$ & 1.0 & 10 & $0(0 / 10)$ & 0.1 & $90(9 / 10)$ & 1.0 \\
\hline Total $^{4}$ & 84 & $57(48 / 84)$ & & $92(77 / 84)$ & & 52 & $31(16 / 52)$ & & $83(43 / 52)$ & \\
\hline
\end{tabular}

${ }^{1}$ Post-vaccination;

${ }^{2}$ Determined by a VN assay. Seropositive cattle were the animals with VN titers of $\geq 0.5 \mathrm{UI} / \mathrm{mL}$;

${ }^{3}$ Geometric mean titer;

${ }^{4}$ Between vaccination and the booster, number of animals decreased from 84 to 52 for reasons unrelated to the experiment. 


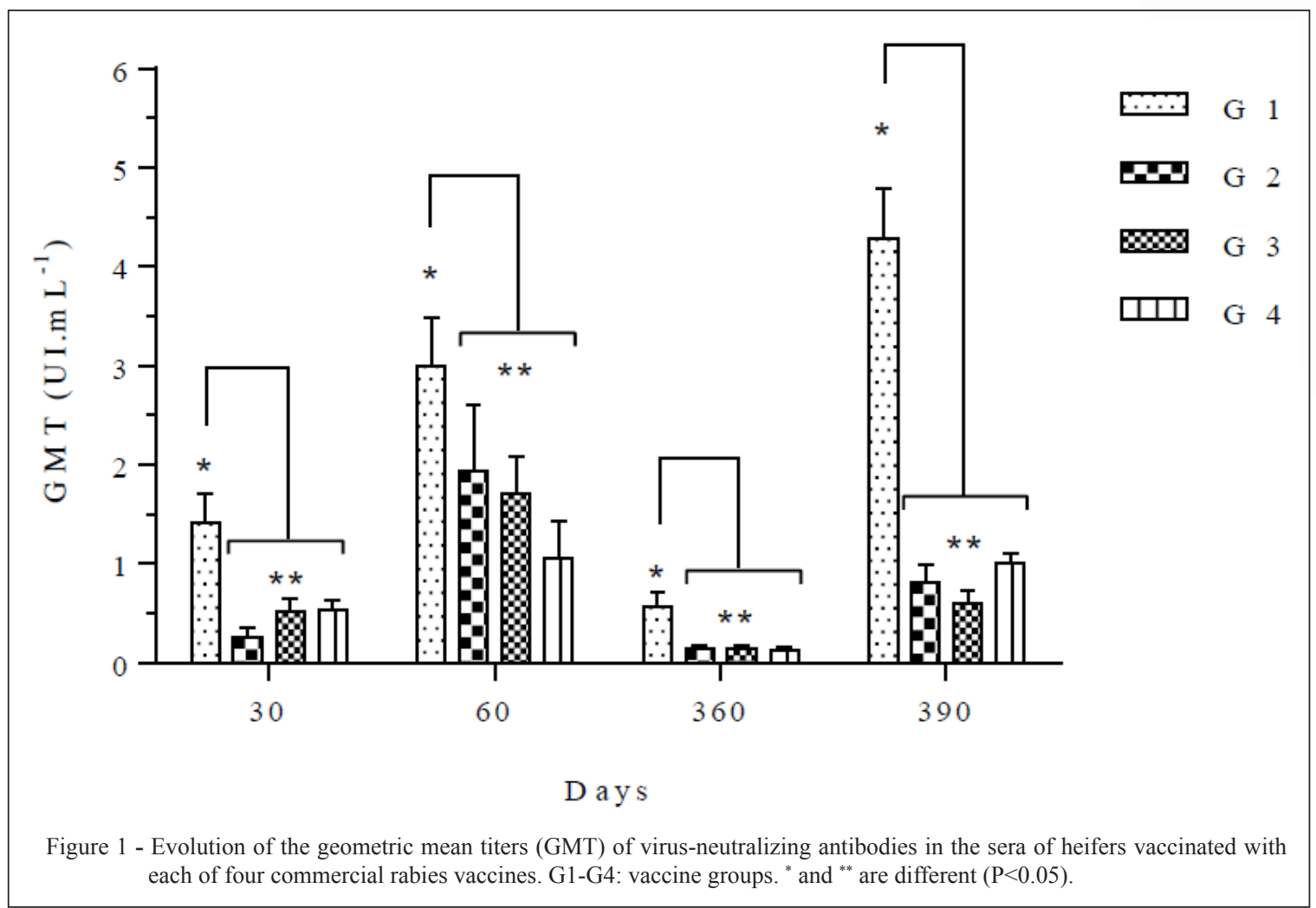

PIZA et al. (2002) verified that the quantification of virus attached rabies glycoprotein present in vaccines, has a strong correlation with VNA elicited in the target species. This could explain the observed differences between the vaccines we tested. However, we did not assess the virus attached rabies glycoprotein, nor total glycoprotein nor free soluble glycoprotein. Thus, it is not possible to attribute the observed differences to this factor. As mentioned before, licensed rabies vaccines are subjected to official control by the Brazilian Ministry of Agriculture Livestock and Supply (MAPA). Our results confirmed the adequate immunogenicity of at least three of these vaccines, as ascertained by VN titers developed in $>95 \%$ animals at day $60 \mathrm{pv}$.

At the day of the booster, the percentage of animals with titers $\geq 0.5 \mathrm{UI} / \mathrm{mL}$ had dropped dramatically comparing to day 60 . Percentage of animals with titers $\geq 0.5 \mathrm{UI} / \mathrm{mL}$ ranged from 0 (G4) to $80 \%$ (G1). These results indicated that approximately $31 \%$ (20 to $100 \%$, depending on the vaccine) of the vaccinated animals would become unprotected to rabies (antibody VN titers lower then $\geq 0.5 \mathrm{UI} / \mathrm{mL}$ ) before the time recommended for booster. At this day, the GMT were also significantly lower $(0.1$ to $0.6 \mathrm{UI} / \mathrm{mL}$ ), illustrating the $\mathrm{VN}$ very low antibody levels after the one year-interval. The fast decline in VN titers induced by inactivated RABV vaccines has also been observed in other studies. ALBAS et al. (2005) evaluated the neutralizing antibody titers 360 after vaccination and observed that none of the nine vaccinated animals was able to maintain adequate antibody titers. In other study, ALBAS et al. (1998) investigated the importance of the booster in the duration of immune response, observing that only $19 \%$ of the animals receiving two vaccine doses, 30 days apart, were able to maintain antibody titers $>0.5 \mathrm{UI} /$ $\mathrm{mL}$ at day 360 . Our results corroborated these findings, indicating an early decrease of neutralizing antibody titers in most vaccinated animals.

Following themanufacturer'srecommendations, we performed a booster vaccination approximately 360 days after the initial vaccination. Sera of vaccinated animals were tested for RABV neutralizing antibodies at the day of the booster and 30 days later. Analyzing the individual vaccines, only G1 was able to maintain adequate antibody levels in a high proportion of animals (80\%) during the oneyear interval. Considering that the vaccination protocols recommend a booster vaccination one year after the prime vaccination, a high percentage of animals (69\%) would be unprotected before receiving the booster. This window of 
susceptibility may partially explain some cases of vaccine failure occasionally reported (LIMA et al., 2005; FILHO et al., 2010). Conversely, these results indicated that shortening the interval between vaccination and booster may be necessary as to eliminate this window of susceptibility, reducing the number of animals susceptible to RABV before booster, as observed in other studies (OLIVEIRA et al., 2000; ALBAS et al., 2005), mainly in young cattle (UMEHARA et al., 2002; LIMA et al., 2005). In hiperendemic areas, where the animals are exposed to a high infection pressure or risk, booster vaccinations at every six or eight months may be required for some vaccines, mainly in the first year after the prime vaccination. A 180 days interval between initial vaccination and booster has been proposed by ALBAS et al. (2005) upon evaluating different vaccination protocols.

Booster vaccination at day 360 resulted in a detectable anamnestic response in all groups as demonstrated by $83 \%$ of animals harboring VN titers $\geq 0.5 \mathrm{UI} / \mathrm{mL}$ at day 390 . The GMT also increased significantly ( 0.6 to $4.3 \geq 0.5 \mathrm{UI} / \mathrm{mL}$ ) (Table 1 , Figure 1 ). Considering the GMT post-booster; however, booster immunization had variable effects among the groups. Only animals in G1 presented a strong anamnestic response, developing GMT $(4.3 \mathrm{UI} / \mathrm{mL})$ higher that those observed after the complete prime vaccination $(3.8 \mathrm{UI} / \mathrm{mL})$. The other vaccines provided a boost sufficient to increase the VN titers of all animals above the value of the $\geq 0.5 \mathrm{UI} / \mathrm{mL}$. However, the GMT of groups G2, G3 and G4 post-booster were significantly lower than those measured at day $60 \mathrm{pv}$ (Figure 1). As the sera was collected 30 days post-booster and the peak of antibody titers may be observed earlier (RODRIGUES DA SILVA et al., 2005), it is possible that slightly higher titers were indeed reached soon after booster. Interestingly, vaccine $\mathrm{G} 4$ had the worst performance at day $60 \mathrm{pv}$, yet provided an adequate immune boost in $90 \%$ of the animals upon revaccination. Unfortunately, we could not follow the animals longer as to ascertain the duration of the post-booster antibodies and whether a shortened interval should also be necessary in the following boosters.

\section{CONCLUSION}

Our results showed that the tested vaccines fulfilled the minimum requirements of immunogenicity, e.g. conferring adequate $\mathrm{VN}$ levels in the vaccinated animals after completion of the prime vaccination protocol. Booster immunization revealed an anamnestic response in all vaccine groups. The significant differences in GMT; however, indicated an important variation in the immunogenicity among the vaccines. The most important finding was that adequate $\mathrm{VN}$ levels were not maintained over the period of one year in $69 \%$ of the animals, indicating the need of shortening the interval between vaccination and booster, mainly in regions of high infection pressure.

\section{INFORMAL INFORMATION}

FLORES, E.F. Setor de Virologia, Departamento de Medicina Veterinária Preventiva, Centro de Ciências Rurais (CCR), Universidade Federal de Santa Maria (UFSM). Av. Roraima, 1000. Camobi, Santa Maria, RS. 97105-900. E-mail: eduardofurtadoflores@gmail.com.

\section{BIOETHICS AND BIOSSECURITY COMMITTEE APPROVAL}

All procedures were approved by an institutional committee of animal use (Comissão de Ética no Uso de Animais (CEUA/UFSM)) (approval protocol n 147/2014).

\section{ACKNOWLEDGEMENTS}

The authors thank the Conselho Nacional de Desenvolvimento Científico e Tecnológico $(\mathrm{CNPq})$ for the scholarships. Mathias M. received doctoral scholarship (process 142148/2011-3), João M.Q. received scientific initiation scholarship (process 135068/2016-9) and Eduardo F.F. (process 301414/2010-6) and Rudi W. (process 304153/2014-1) were supported by research productivity fellowship.

\section{REFERENCES}

ALBAS, A. et al. Effect of a booster-dose of rabies vaccine on the duration of virus neutralizing antibody titers in bovines. Revista da Sociedade Brasileira de Medicina Tropical, v.31, n.4, p.367-371, 1998. Available from: $<$ http://www.scielo.br/scielo.php?script=sci arttext\&pid $=$ S0037-86821998000400006\&lng $=$ en\&nrm $=$ iso $>$. Accessed: Oct. 05, 2016. doi: 10.1590/S0037-86821998000400006.

ALBAS, A. et al. Rabies vaccination in cattle: comparison between five vaccinal schedules. Arquivos do Instituto Biológico, v.72, n.2, p.153-159, 2005. Available from: <http://www.biologico.sp.gov.br/ docs/arq/V72_2/albas.PDF $>$. Accessed: Oct. 10, 2016.

CONDORI-CONDORI, R.E. et al. Enzootic and epizootic rabies associated with vampire bats, Peru. Emerging Infectious Diseases, v.9, n.9, p.1463-1469, 2013. Available from: <https://www.ncbi.nlm. nih.gov/pmc/articles/PMC3810916/>. Accessed: Mar. 30, 2017. doi: 10.3201/eid1909.130083.

CÔRTES, J.A. et al. Immune response in cattle induced by inactivated rabies vaccine adjuvanted with aluminium hydroxide either alone or in combination with avridine. Revue Scientifique et Technique. Office International des Épizooties, v.12, p.941-955, 1993. Available from: $<$ http://www.oie.int/doc/ged/D8766.PDF>. Accessed: Oct. 08, 2016.

ITO, F.H. et al. Course of humoral immune response shortly after revaccination with $\mathrm{BHK}-21$ cell culture inactivated rabies vaccine adjuvanted with aluminium hydroxide. Brazilian Journal Veterinary Research and Animal Science, v.28, n.1, p.51-57, 1991. Available from: $<$ http://www.revistas.usp.br/bjvras/article/viewFile/51924/55975>. Accessed: Oct. 15, 2016. 
JOHNSON, N. et al. Vampire bat rabies: ecology, epidemiology and control. Viruses, v.6, n.5, p.1911-1928, 2014. Available from: $<$ http://www.mdpi.com/1999-4915/6/5/1911/htm>. Accessed: Oct. 15, 2016. doi: $10.3390 / \mathrm{v} 6051911$.

HEINEMANN, M.B. et al. Genealogical analyses of rabies virus strains from Brazil based on $\mathrm{N}$ gene alleles. Epidemiology and Infection, v.128, p.503-511, 2002. Available from: <https://www. ncbi.nlm.nih.gov/pmc/articles/PMC2869848/>. Accessed: Oct. 10, 2016. doi: $10.1017 / \mathrm{S} 095026880200688 \mathrm{X}$.

FILHO, O.A. et al. Importance of antirabies revaccination for an adequate antirabies protection in bovine newborn. Clinical Vaccine Immunology, v.17, n.7, p.1159-1161, 2010. Available from: <https:// www.ncbi.nlm.nih.gov/pmc/articles/PMC2897266/>. Accessed: Oct. 15, 2016. doi: 10.1128/CVI.00119-10.

LIMA, E.F. et al. Clinical signs, clinical signs, distribution of the lesions in the central nervous system and epidemiology of rabies in northeastern Brazil. Pesquisa Veterinária Brasileira, v.25, n.4, p.250-264, 2005. Available from: <http://www.scielo.br/scielo.php?script=sci_ arttext\&pid=S0100-736X2005000400011\&lng $=$ pt\&nrm=iso $>$. Accessed: Oct. 14, 2016. doi: 10.1590/S0100-736X2005000400011.

MAPA (MINISTÉRIO DA AGRICULTURA PECUÁRIA E ABASTECIMENTO), 2009. Available from: $<$ http://www.agricultura. gov.br/arq_editor/file/Aniamal/programa $\% 20$ nacional $\% 20 \mathrm{dos} \% 20$ herbivoros $/$ manual $\% 20$ tecnico $\% 20$ para $\% 20$ controle $\% 20 \mathrm{da} \% 20$ raiva.pdf $>$. Accessed: Oct. 17, 2016.

OIE(ORGANIZATION OF INTERNATIONALANIMAL HEALTH), 2016. Available from: <http://www.oie.int/en/animal-health-in-theworld/rabies-portal/about-rabies/>. Accessed: Oct. 17, 2016.

OLIVEIRA, A.N. et al. Immune response in cattle vaccinated against rabies. Memórias do Instituto Oswaldo Cruz, v.95, n.1, p.83-88, 2000. Available from: $<$ http://www.scielo.br/scielo.php?script $=$ sci arttext\&pid=S0074-02762000000100013\&lng $=$ en\&nrm $=$ iso $>$. Accessed: Oct. 17, 2016. doi: 10.1590/S0074-02762000000100013.

PERKINS, F.T. A ready reckoner for the calculation of geometric mean antibody titres. Journal General Microbiology, v.19, p.540541, 1958. Available from: <http://www.microbiologyresearch. org/docserver/fulltext/micro/19/3/mic-19-3-540.pdf?expires $=1476$ 752917\&id=id\&accname $=$ guest $\&$ checksum $=91240 \mathrm{AC} 2365 \mathrm{EF} 3 \mathrm{~A}$ E22A99426A30C14E3>. Accessed: Oct. 15, 2016.

PIZA,A.T. etal. Effect of the Contents and Form of Rabies Glycoprotein on the Potency of Rabies Vaccination in Cattle. Memórias do Instituto Oswaldo Cruz, v.97, n.2, p.265-268, 2002. Available from: $<$ http://www.scielo.br/scielo.php?script=sci_arttext\&pid=S007402762002000200022\&lng=en\&nrm=iso>. Accessed: Mar. 30, 2017. doi: 10.1590/S0074-02762002000200022.
QUEIROZ DA SILVA, L.H. et al. Antibody response against rabies virus in vaccinated cattle from Araçatuba region, state of São Paulo, Brazil, SP. Arquivos do Instituto Biológico, v.70, n.4, p.407-413, 2003. Available from: <http://www.biologico.sp.gov. br/docs/arq/V70_4/silva2.pdf $>$. Accessed: Oct. 12, 2016.

RIBEIRO NETTO, A. et al. Comparative study of cattle antirabies vaccines. Zentralblatt für Veterinärmedizin Reihe B, v.20, n.5, p.398-404, 1973.

RODRIGUES DA SILVA, A.C. et al. Antibody response in cattle after vaccination with inactivated and attenuated rabies vaccines. Revista do Instituto de Medicina Tropical de São Paulo, v.42, n.2, p.95-98, 2000. Available from: <http://www.scielo.br/scielo. php? script $=$ sci arttext\&pid $=$ S0036-46652000000200006\&lng $=$ en\&nrm=iso $>$. Accessed: Oct. 15, 2016. doi: 10.1590/S003646652000000200006.

SCHNEIDER, M.C. et al. Rabies transmitted by vampire bats to humans: an emerging zoonotic disease in Latin America? Revista Panamericana de Salud Pública, v.25, n.3, p.260269, 2009. Available from: <http://www.scielosp.org/scielo. php?script=sci_arttext\&pid=S1020-49892009000300010\&lng $=$ en\&nrm $=$ iso $>$. Accessed: Mar. 30, 2017. doi: 10.1590/S102049892009000300010.

SEAPA. Noticias. Assessoria de Imprensa. Secretaria da Agricultura Pecuária e Agronegócio, Porto Alegre, 21 jun. 2013. Available from: $<$ http:// www.agricultura.rs.gov.br/conteudo/4270/?Raiva_j\%C3\%A1_matou_ quatro_mil_animais_no_Estado_em_2013>. Accessed: Oct. 17, 2016.

SMITH, J.S. et al. A rapid reproducible test for determining rabies neutralizing antibody. Bulletin of the World Health Organization, v.48, n.5, p.535-541, 1973. Available from: <https://www.ncbi. nlm.nih.gov/pmc/articles/PMC2482941/pdf/bullwho00178-0027. pdf $>$. Accessed: Oct. 17, 2016.

UMEHARA, O. et al. Rabies virus neutralizing antibody profile in cattle vaccinated with inactivated vaccine adjuvanted with either aluminum hydroxide alone or combined with avridine. Arquivos do Instituto Biológico, v.69, n.1, p.23-28, 2002. Available from: $<$ http://revistas.bvs-vet.org.br/arqib/article/view/27522>. Accessed: Oct. 04, 2016.

WIKTOR, T.J. et al. Antigenic properties of rabies virus components. Journal of Immunology, v.110, n.1, p.269-276, 1973. Available from: $<$ http://www.jimmunol.org/content/110/1/269.full.pdf + html $>$. Accessed: Oct. 17, 2016.

WUNDERLI, P.S. et al. The protective role of humoral neutralizing antibody in the NIH potency test for rabies vaccines. Vaccine, v.9, n.9, p.638-642, 1991. Available from: <http://www.sciencedirect.com/ science/article/pii/0264410X9190188C > . Accessed: Oct. 17, 2016. 


\section{Erratum}

In the article "Serological response to rabies virus induced by commercial vaccines in cattle" published in Ciência Rural, volume 47, number 10, DOI http://dx.doi.org/10.1590/0103-8478cr20161044.

In several moments in the article, where it reads:

$\mathrm{UI} / \mathrm{mL}$

Read it:

$\mathrm{UI} \mathrm{mL} L^{-1}$

In the Abstract, where it reads:

At the day of the booster (360 days post-vaccination); however

Read it:

However, at the day of the booster (360 days post-vaccination)

In the Resumo, where it reads:

GMT

Read it:

TMG (título médio geométrico)

In the Materials and Methods, where it reads:

Sao Paulo

Read it:

São Paulo

In the table 1, where it reads:

pv

Read it:

$\mathrm{dpv}$ 
Where it reads:

Post-vaccination

Read it:

Days post-vaccination

In the Results and Discussion, where it reads:

antibody VN titers lower then $\geq 0.5 \mathrm{UI} / \mathrm{mL}$

Read it:

antibody VN titers lower then $0.5 \mathrm{UI} \mathrm{mL} \mathrm{m}^{-1}$

Where it reads:

( 0.6 to $4.3 \geq 0.5 \mathrm{UI} \mathrm{mL}^{-1}$ )

Read it:

(0.6 to $4.3 \mathrm{UI} \mathrm{mL}^{-1}$ ) 